VOL. 1, No. 1, Juni 2017, h.13-24

ISSN 2580-0620 (Print)

Available Online at https://jurnal.unsur.ac.id/index.php/JE

\title{
PEMBENTUKAN KOPERASI WUJUD KEPEDULIAN PENINGKATAN TARAF KEHIDUPAN PARA PETANI DI DESA LENGANSARI KECAMATAN SUKARAJA KABUPATEN SUKABUMI
}

\author{
Ari Riswanto \\ Program Studi Pendidikan Ekonomi-STKIP PGRI Sukabumi \\ email: aririswanto@stkippgrisukabumi.ac.id
}

\begin{tabular}{|l|l|l} 
Masuk : Maret 2017 & Penerimaan : Maret 2017 & Publikasi : Juni 2017
\end{tabular}

\begin{abstract}
ABSTRAK
Peningkatan kapasitas perempuan untuk bertahan hidup merupakan sesuatu hal yang harus senantiasa diperjuangkan oleh mahkluk yang ada di dunia ini. Desa Lengansari Kecamatan Sukaraja Kabupaten Sukabumi menjadi potret perjuangan para warga yang hanya dapat bekerja sebagai buruh tani ditempat tinggalnya sendiri. Fenomena ini melahirkan ide dalam kegiatan pengabdian pada masyarakat yang merupakan program tahunan STKIP PGRI Sukabumi. Kelompok III yang berlokasi di Desa Lengansari menggagas pembentukan koperasi sebagai wujud kepedulian masyarakat pendidikan terhadap peningkatan taraf kehidupan masyarakat desa. Pembinaan pun dilakukan secara kondusif dan terprogram oleh team yang diarahkan oleh dosen pembimbing guna mewujudkan harapan yang diinginkan oleh warga masyarakat di Desa Lengansari. Kegiatan ini disukseskan berkat kerja keras dari Mahasiswa kelompok III yang berjumlah 25 orang mahasiswa didamping seorang dosen pembimbing dan bekerjasama dengan aparatur terkait baik di wilayah desa ataupun dengan dinas perkoperasian.
\end{abstract}

Kata Kunci: Pembentukan Koperasi, Peningkatan Taraf Hidup, dan Buruh Tani Desa.

\begin{abstract}
The increasing of women capacity to survive is something that must always be fought. Lengansari village of Sukaraja District of Sukabumi is the representative of the struggling people who are always be the farm laborers on their own dwelling place. This phenomenon triggered the idea of the community service activities which is be an annual program of STKIP PGRI Sukabumi. Group III that is located in Lengansari village initiated to establish a cooperative as a form of education to increase the public standard of living of rural communities. In order to gain the villagers' expectation, the training was done conductively and systematically by a team under the lecturer guidance. This project was successfully gained because of the hard work of the students of group III totaling 25 students who were directed by the lecturer and in collaboration both with the related apparatus in the region and the department of cooperatives.
\end{abstract}

Keywords: Cooperation Establishment; Increasing Living Standard; and Village Labour. 


\section{A. PENDAhUlUAN}

\section{Latar Belakang}

Desa Lengansari dikenal sebagai sebuah desa yang perekonomiannya bertonggak pada pertanian. Berbagai jenis tanaman tumbuh subur di desa ini. Namun, mata pencaharian hampir $90 \%$ warga desa Lengansari yang bekerja menggarap sawah dan perkebunan adalah bukan petani melainkan sebagai buruh tani. Kenyataan tersebut menjadi sebuah fakta miris dimana 25 Ha sawah dan 329,352 $\mathrm{Ha}$ perkebunan dan kehutanan di Desa Lengansari sebagian kecil dimiliki petani dengan jumlah 159 orang petani dan sebagian besarnya dikelola oleh buruh tani dengan jumlah 1.221 orang buruh tani.

Kekayaan alam yang seharusnya mengangkat tingkat kesejahteraan masyarakat setempat malah dimiliki orang lain sehingga masyarakat tetap berada di level sejahtera yang sama tiap tahunnya dan dibutuhkan sebuah program berkelanjutan untuk meningkatkannya. Sumber daya alam, sumber daya manusia dan sumber daya modal harus bersinergi membentuk suatu simbiosis mutualisme untuk memberikan keuntungan lebih bagi pelakunya. Desa Lengansari telah memiliki sumber daya alam yang memadai berupa lahan-lahan pertanian dan perkebunan yang subur, sumber daya manusia yang telah cakap menggarap sumber daya alam karena telah sangat lama praktik bertani dan sumber daya manusia yang telah terpelajar melalui seminar-seminar pertanian yang diadakan lembaga pemerintah maupun non pemerintah. Namun, sumber daya modal yang belum terkelola dengan baik menjadikan petani Desa Lengansari kalah saing dalam pemilikan lahan di tanah kelahirannya.
Karena itu, kami Kelompok III KKN STKIP PGRI Sukabumi mencari alternatif sederhana bagi masyarakat untuk meningkatkan taraf kesejahteraan petani Desa Lengansari. Dari berbagai opsi peluang usaha, koperasi dirasa mampu menunjang kebutuhan modal petani Desa Lengansari, sifatnya yang kekeluargaan dan sederhana akan mudah dipahami dan diterima masyarakat. Untuk menjalankan program pembentukan koperasi ini, kami menemui Badan Permusyawaratan Desa (BPD) Lengansari agar mendapat rujukan mengenai data koperasi di Desa Lengansari. Salah satu koperasi yang ada di Desa Lengansari adalah Koperasi Mitra Harapan Tani (KOPMIHAT) yang sayang sekali sudah tidak beroperasi sejak pengurusnya meninggal. Kemudian Bapak Ketua BPD menunjukkan kami untuk menemui kelompok Tani Bibilintik II di Kp. Cibalung RT. 04 RW. 05 desa Lengansari kecamatan Sukaraja Kabupaten Sukabumi. Kelompok tani ini dinilai berprestasi karena keanggotaan yang cukup aktif dan eksistensinya telah sampai pada tingkat provinsi Jawa Barat sehingga banyak bantuan hibah alat pertanian yang diterima.

Kelompok Tani Bibilintik II terbentuk pada tahun 2008 saat teknologi pertanian masih sangat sederhana. Kelompok Tani ini diketuai oleh Bapak Asep dan manajerial diatur oleh lbu Yuyu. Keunikan kelompok tani Bibilintik II dibanding kelompok tani lainnya di Desa Lengansari adalah bahwa kelompok tani Bibilintik II merupakan gabungan petani padi sedangkan kebanyakan kelompok Tani Desa Lengansari adalah gabungan petani bunga. Anggota yang telah tergabung pada Kelompok Tani Bibilintik II terhitung 
berjumlah 70 anggota. Terdiri dari masyarakat lokal dan masyarakat setempat lintas kecamatan. Kelompok Tani ini merupakan kelompok tani hamparan, artinya anggota kelompok tani merupakan mereka yang memiliki hamparan lahan di daerah kelompok tani Bibilintik II yakni Kp. Cibalung RW. 05 Desa Lengansari.

Prestasi kelompok Tani Bibilintik II telah dikenal hingga tahap pemerintah provinsi karena hasil tani yang baik dan keaktifan anggota yang terus berkembang mulai tahun 2012 saat teknologi mulai masuk. Kelompok tani ini diharapkan mampu menjadi ikon desa yang membawa petani desa menjadi petani pembelajar yang terus mengikuti perkembangan pertanian dan meningkatkan mutu pertanian. Masuknya teknologi ke kelompok Tani Bibilintik II ini tidak di dapat dari merogoh kocek sendiri, melainkan dengan bantuan dana hibah pemerintah melalui pengajuan proposal dan lainnya. Beberapa teknologi pertanian yang telah dimiliki Kelompok Tani Bibilintik II dari dana hibah diantaranya; transplanter, traktor, mesin penggiling padi, kombin dan lainlain.

Manajerial kelompok tani Bibilintik II yang dikelola oleh ibu Yuyu begitu baik terbukti dengan sering masuknya dana hibah dari pemerintah dan baiknya hasil tani yang dihasilkan. Keaktifan pengelola dalam mengikuti seminar pertanian sangat berpengaruh pada kemajuan kelompok tani ini. Program-program pertanian yang telah dijalankan Kelompok Tani Bibilintik II diantaranya adalah tanam serempak, tanam legowo dan pemupukan berimbang. Sebagai sebuah bentuk syukur dan kompaknya Kelompok Tani Bibilintik II maka setiap tahun diadakan sebuah agenda yang disebut panen raya. Kegiatan ini diadakan dengan mengundang perwakilan pejabat desa, pemerintah daerah setempat, dan pejabat lain yang terkait di dalamnya berpengaruh pada kelompok tani Bibilintik II. Potensi seperti ini dirasa mampu dan sangat mampu menjadi cikal bakal perkembangan pertanian di Desa Lengansari. Sinergi sumber daya alam dan manusia telah sinkron. Sehingga, hanya perlu satu koneksi lagi pada sumber daya modal untuk memaksimalisasi keberadaan Kelompok Tani Bibilintik II di Desa Lengansari.

\section{Lokasi Pengabdian}

Pengabdian pada masyarakat kali ini berlokasi di Desa Lengansari, Kecamatan Sukaraja-Kabupaten Sukabumi dan dilaksanakan pada bulan Mei 2016.

\section{Peserta}

Peserta yang terlibat dalam kegiatan Pengabdian kali ini adalah berasal dari mahasiswa STKIP PGRI Sukabumi semester VI dengan jumlah 25 mahasiswa dan dibimbing oleh 1 orang dosen pendamping.

\section{B. METODE}

Waktu penelitian ini dilaksanakan pada bulan Mei 2016. Lokasi penelitian ini dilaksanakan di Kecamatan Sukaraja Kabupaten Sukabumi. Jenis penelitian yang digunakan pada penelitian ini ialah kualitatif, artinya data yang dikumpulkan bukan berupa angkaangka melainkan data tersebut berasal dari hasil wawancara, catatan lapangan, dokumen pribadi, catatan memo, dan dokumen resmi lainnya dan Tipe Penelitian ini 
dikategorikan sebagai penelitian tipe eksploratif dengan pendekatan kualitatif. Sumber data yang digunakan ialah Data Primer dan data sekunder. ${ }^{1}$

Dalam penelitian ini, yang menjadi informan ialah para peserta pembentukan koperasi. Untuk mendapatkan data yang akurat peneliti menggunakan tiga teknik pengumpulan data, yaitu observasi, wawancara dan dokumentasi. Teknik analisis data yang digunakan dalam penelitian ini adalah analisis deskriptif kualitatif yaitu dengan menguraikan serta menginterpretasikan data yang di peroleh dari proses mengorganisasikan dan mengurutkan data yang diperoleh dari lapangan dan dari para informan ke dalam pola, kategori, dan suatu uraian dasar sehingga dapat di temukan tema dan dirumuskan hipotesis kerja seperti yang disarankan oleh data. Ada tiga unsur utama dalam proses analisis data penelitian kualitatif, yaitu: Reduksi Data adalah bagian dari proses analisis yang mempertegas, memperpendek dan membuang halhal yang tidak penting sehingga kesimpulan penelitian dapat dilaksanakan. Jadi laporan lapangan sebagian bahan disingkat dan disusun lebih sistematis sehingga lebih mudah dikendalikan. ${ }^{2}$ Data yang direduksi memberi gambaran yang lebih tajam tentang hasil pengamatan, juga mempermudah peneliti untuk mencari kembali data yang diperoleh apabila diperlukan, Penyajian Data adalah susunan

Rakhmat, Jalaludin, (2000), Metode Penelitian Komunikasi, Bandung, Remaja Rosdakarya, hlm. 34-35.

Moleong, Lexy J, (1991), Metode Penelitian Kualitatif, Bandung, Remaja Rosda Karya, hlm. 86-87. informasi yang memungkinkan dapat ditariknya suatu kesimpulan penelitian. Penyajian data dalam bentuk gambaran, skema, dan tabel mungkin akan berguna mendapatkan gambarkan yang serta memudahkan dalam penyusunan kesimpulan penelitian. Pada dasarnya, saijan data dirancang untuk menggambarkan suatu informasi secara sistematis dan mudah dilihat serta dipahami dalam bentuk keseluruhan sajiannya, Kesimpulan merupakan hasil akhir dari reduksi data dan penyajian data. Kesimpulan penelitian merupakan verifikasi agar mantap dan benar-benar bisa dipertanggungjawabkan kebenarannya. ${ }^{3}$

\section{PEMBAHASAN}

1. Landasan Filosofis, Akademis dan Hukum

a. Landasan Filosofis

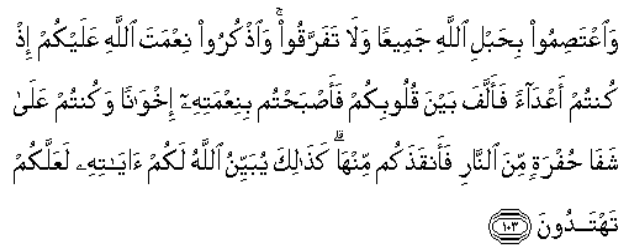

"Dan berpegang teguhlah kamu semuanya pada tali (agama) Allah dan janganlah kamu bercerai berai, dan ingatlah nikmat Allah kepadamu ketika kamu dahulu (masa jahiliyah) bermusuhan, lalu Allah mempersatukan hatimu, sehingga dengan karunia-Nya kamu menjadi bersaudara, sedangkan (ketika itu) kamu berada di tepi jurang neraka, lalu Allah menyelamatkan kamu dari sana. Demikianlah Allah menerangkan ayat-ayat-Nya kepadamu agar

Herdiansyah, Haris, (2010), Metode penelitian kualitatif, Jakarta, Salemba Humanika, hlm. 23. 
kamu mendapat petunjuk". Q.S. Ali Imran ayat 103.

Koperasi merupakan gerakan ekonomi rakyat yang bertujuan untuk menyejahterakan anggotanya. Koperasi berlandaskan asas kekeluargaan sehingga hubungan tiap-tiap anggotanya sangat erat. Undang-Undang Nomor 25 Tahun 1992, memberikan definisi "Koperasi adalah badan usaha yang beranggotakan orang-orang atau badan hukum koperasi yang melandaskan kegiatannya berdasarkan prinsip koperasi sekaligus sebagai gerakan ekonomi rakyat yang berdasar atas asas kekeluargaan".

Definisi koperasi yang lebih detail dan berdampak internasional diberikan oleh ILO sebagai berikut:

"Cooperative defined as an association of persons usually of limited means, who have voluntarily joined together to achieve a common economic end through the formation of a democratically controlled business organization, making equitable contribution to the capital required and accepting a fair share of risk and benefits of undertaking". ${ }^{4}$

Dalam definisi ILO tersebut, terdapat 6 elemen yang dikandung koperasi sebagai berikut:

1) Koperasi adalah perkumpulan orang-orang (Association of persons).

2) Penggabungan orang-orang tersebut berdasar

Ilo, (2015), Cooperatives and the Sustainable Development Goals: A Contribution to the Post2015 Development Debate A Policy Brief. International Labour Organization: International Cooperative Alliance, hlm. 1617. kesukarelaan (Voluntarily joined together).

3) Terdapat tujuan ekonomi yang ingin dicapai (to achieve a common economic end).

4) Koperasi yang dibentuk adalah satu organisasi bisnis (badan usaha) yang diawasi dan dikendalikan secara demokratis (formation of a democratically controlled business organization)

5) Terdapat kontribusi yang adil terhadap modal yang dibutuhkan (making equitable contribution to the capital required)

6) Anggota koperasi menerima risiko dan manfaat secara seimbang (Accepting a fair share of the risk and benefits of the undertaking).

Menurut Hatta, untuk disebut koperasi, sesuatu organisasi itu setidak-tidaknya harus melaksanakan 4 asas. Asas-asas tersebut adalah:

1) Tidak Boleh dijual dan diedarkan barang-barang palsu

2) harga barang harus sama dengan harga pasar setempat

3) Ukuran harus benar dan dijamin

4) Jual beli dengan Tunai. Kredit dilarang karena menggerakkan hati orang untuk membeli di luar kemampuannya.

Berdasarkan batasan koperasi, koperasi Indonesia mengandung 5 unsur sebagai berikut:
1) Koperasi adalah badan usaha (Business Enterprise);
2) Koperasi adalah kumpulan orang-orang dan atau badan- badan hukum koperasi;
3) Koperasi Indonesia adalah koperasi yang bekerja berdasarkan "prinsip-prinsip koperasi";


4) Koperasi Indonesia adalah "Gerakan Ekonomi Rakyat";

5) Koperasi Indonesia "berazaskan kekeluargaan".

Kelompok adalah sekumpulan orang yang mempunyai tujuan bersama, yang berinteraksi satu sama lain untuk mencapai tujuan bersama, mengenal satu sama lainnya, dan memandang mereka sebagai bagian dari kelompok tersebut. ${ }^{5}$ Kelompok tani adalah petani yang dibentuk atas dasar kesamaan kepentingan kesamaan kondisi lingkungan (sosial, ekonomi, sumberdaya) keakraban dan keserasian yang dipimpin oleh seorang ketua. $^{6}$ Kelompok Tani menurut Anonim diartikan sebagai kumpulan orang-orang tani atau yang terdiri dari petani dewasa (pria/wanita) maupun petani taruna (pemuda/pemudi) yang terikat secara formal dalam suatu wilayah keluarga atas dasar keserasian dan kebutuhan bersama serta berada di lingkungan pengaruh dan pimpinan seorang kontak tani. ${ }^{7}$

b. Landasan Akademis

Koperasi merupakan jati diri bangsa Indonesia dimana sifat-sifatnya diadaptasi dari sifat bangsa Indonesia yang ramah dan kekeluargaan. Tergerak dari kesadaran untuk bekerjasama dalam membangun perekonomian rakyat menuju cita-cita bersama yakni sejahtera. Koperasi merupakan sebuah lembaga ekonomi yang

Sitio, Arifin Dkk, (2006), Koperasi: Teori dan Praktek, Jakarta, Erlangga, hlm. 17-18.

6 Trimo, S, (2006), Evaluasi Penyuluhan Pertanian Permasalahan dan Upaya Pemecahannya di Kecamatan Banyudono Kabupaten Boyolali. Jurnal Penyuluhan, Vol. 2, hlm. 4.

Mardikanto, T, (1993), Penyuluhan Pembangunan Pertanian, Surakarta: Sebelas Maret University Press, hlm. 112-113. sangat menjunjung tinggi nilai-nilai ke-Indonesia-an melalui sistem kerianya yang berbentuk gotong royong. Secara akademis, koperasi merupakan bentuk lembaga yang sangat pro rakyat sehingga sangat tepat untuk dibangun di atas persatuan masyarakat. Simpanansimpanan yang dititipkan anggota koperasi nantinya akan terakumulasi dan dapat dijadikan kekuatan modal dimana harapannya adalah anggota menggunakan kekuatan modal tersebut untuk kepentingan pengembangan usaha pertaniannya baik dalam hal pemilikan lahan ataupun yang lainnya.

\section{c. Landasan Hukum}

Koperasi merupakan badan usaha berbadan hukum yang pengesahan pendiriannya dilakukan oleh Menteri Negara Koperasi dan UKM atau pejabat dinas/instansi/badan yang membidangi koperasi setempat sesuai domisili anggota (UndangUndang Nomor 25 Tahun 1992 tentang Koperasi Pasal 5 ayat 3 ) (Presiden Republik Indonesia, 1992). ${ }^{8}$ Sedangkan, dalam bab II Pasal 2 dinyatakan bahwa landasan dan asas koperasi berdasarkan Pancasila dan Undang-Undang Dasar 1945 serta berdasarkan atas asas kekeluargaan. ${ }^{9}$

Landasan Hukum Koperasi ada 3 yaitu:

1) Landasan idiil

Landasan idiil koperasi adalah pancasila. Dimana kelima sila dari pancasila tersebut harus dijadikan dasar dalam

Presiden Republik Indonesia, (1992), Undang-Undang Republik Indonesia Nomor 25 Tahun 1992 Tentang Perkoperasian, hlm. 13.

9 Thoby, Mutis, (2004), Pengembangan Koperasi, Jakarta, Grasindo, hlm. 45. 
kehidupan koperasi di Indonesia. Dasar idiil ini harus diamalkan oleh seluruh anggota maupun pengurus koperasi karena pancasila disamping merupakan dasar negara juga sebagai falsafah hidup bangsa dan negara Indonesia.

2) Landasan Struktural

Landasan struktural koperasi adalah Undang-Undang Dasar 1945. Sebagai landasan geraknya adalah Pasal 33 Ayat (1), UUD 1945 serta penjelasannya. Menurut Pasal 33 Ayat (1) UUD 1945: Perekonomian disusun sebagai usaha bersama atas asas kekeluargaan.

3) Landasan Mental

Landasan mental koperasi Indonesia adalah setia kawan dan kesadaran berpribadi. Landasan itu mencerminkan dari kehidupan bangsa yang telah berbudaya, yaitu gotong royong. Setia kawan merupakan landasan untuk bekerjasama berdasarkan atas asas kekelvargaan. Kesadaran berpribadi, keinsafan akan harga diri sendiri, merupakan hal yang mutlak harus ada dalam rangka meningkatkan derajat kehidupan dan kemakmuran. Kesadaran berpribadi juga merupakan rasa tanggung jawab dan disiplin terhadap segala peraturan hingga koperasi akan terwujud sesuai dengan tujuannya. ${ }^{10}$
10 Firdaus, Agus Edhi Susanto, (2002), Perkoperasian Sejarah, Teori dan Praktek, Jakarta, Ghalia Indonesia, hlm. 9.

\section{Implikasi Masalah Terhadap Pembangunan Desa \\ a) Implikasi Terhadap Pembangunan Desa}

Telah menjadi hukum alam bahwa manusia menanam untuk memanen. Petani menanam benih padi hari ini untuk memanen padi enam bulan ke depan, investor menanam saham untuk memanen keuntungan, guru menanam ilmu untuk memanen generasi gemilang, begitu terus setiap usaha yang dilakukan seseorang merupakan benih yang ia tanam untuk dipanen kemudian. Kelompok Tani Bibilintik II yang merupakan gabungan petani padi hamparan Kp. Cibalung Rw. 05 menanam benih padi pada pesawahannya untuk memanen padi dengan kualitas terbaiknya. Untuk memperoleh kualitas padi terbaik tersebut, pengelola kelompok tani banyak mengikuti seminar pertanian yang kemudian disosialisasikan kepada anggota kelompok tani untuk kemudian di aplikasikan dalam pengelolaan lahan pertaniannya.

Hambatan yang terjadi pada kemajuan kelompok tani adalah ketakutan-ketakutan anggota kelompok tani pada kegagalan panen jika mengikuti saran-saran pengelolaan pertanian modern sehingga pengurus kelompok tani harus mengaplikasikan pada lahan pertaniannya dahulu dan jika terbukti sukses, barulah yang lain mengikuti cara tersebut. Kefanatikan pemikiran pada cara-cara lama seperti yang telah digambarkan sebelumnya sering kali menjadi hambatan utama kemajuan. Memang, pada dasarnya kebanyakan petani lebih menyukai cara lamanya karena telah terbukti panen pada tahun-tahun sebelumnya. Namun, perkembangan zaman menuntun petani untuk menyesuaikan 
diri. Misalnya pada porsi pemupukan, jika misal dulu menggunakan perbandingan 1:1 pemupukan perlahan maka sekarang menurut pertanian modern harus dikurangi menjadi 1/2: 1 karena banyaknya limbah rumah tangga melalui pengairan sawah yang berakibat pada pertumbuhan padi. Untuk memaksimalkan hasil kerja petani, kami berharap petani memiliki garapan pribadi di atas lahan pertaniannya sendiri. Untuk itu dicanangkan pembentukan koperasi agar dana simpanan anggota dapat digulirkan melalui pinjaman untuk pembelian lahan pertanian sehingga hasil tani akan sangat terasa manfaatnnya bagi petani. Dan pekerjaan sebagai buruh tani diharap dapat berubah menjadi petani produktif. Tujuan lainnya adalah tercapainya kesejahteraan petani, selain itu koperasi bias menjadi ujung tombak pengelolaan berkelanjutan sumber daya alam untuk anak cucu, koperasi Model tata kelola dapat menyediakan kerangka kerja bagi proses partisipatif yang adil yang menjamin transparansi dan akuntabilitas, bekerja sama dengan masyarakat, pemerintah, bisnis dan pemangku kepentingan lainnya untuk mewujudkan berkelanjutan pengembangan. ${ }^{11}$ Seperti halnya yang terjadi di salah satu negara bahwa koperasi secara perlahan membuat dampak di seluruh daerah pedesaan Armenia. Koperasi memiliki potensi dan kekuatan yang sangat besar untuk menjadi salah satu pilar dalam pembangunan suatu negara khususnya dengan bersatunya petani dapat mengubah kehidupan lingkungan mereka sendiri dan

11 Hendar, Kusnadi, (2005), Ekonomi Koperasi Edisi Kedua, Jakarta, Fakultas Ekonomi UI, hlm. 87. kehidupan secara keseluruhan komunitas yang mereka miliki. ${ }^{12}$

Koperasi Kelompok Tani Bibilintik II bukanlah koperasi yang didirikan tanpa kerja keras. Meskipun pembinaan pembentukan yang kami lakukan terbilang singkat, melalui tiga pertemuan lalu terbentuklah koperasi yang disepakati bersama dengan namanya yang telah disebut di atas. Pembinaan tersebut dapat dijabarkan sebagai berikut:

1) Pertemuan I Rabu 18 Mei 2016, kami bertemu Bapak Asep selaku ketua Kelompok Tani Bibilintik II dan Ibu Yuyu selaku manajer Kelompok Tani Bibilintik II berbincang mengenai gambaran umum kelompok tani Bibilintik II dan menyinggung sedikit mengenai pendirian koperasi yang disambut hangat oleh Ibu Yuyu.

2) Pertemuan II Rabu 25 Mei 2016 pengenalan koperasi kepada anggota Kelompok Tani Bibilintik II di kediaman lbu Yuyu Kp. Cibalung Rt. 04/05 yang diterima baik dan diperoleh kesepakatan pembentukan koperasi sehingga langsung membuat AD/ ART Koperasi yang disepakati bernama Koperasi Kelompok Tani Bibilintik II.

3) Pertemuan III Selasa 31 Mei 2016, peresmian terbentuknya Koperasi Kelompok Tani Bibilintik Il di kediaman ibu Yuyu.

Pengurus yang disepakati dalam forum pembentukan koperasi merupakan susunan pengurus kelompok Tani Bibilintik II, sebagai berikut:

12 Pachta W, Andjar, Dkk, (2007), Hukum Koperasi Indonesia pemahaman, regulasi, pendidikan, dan modal usaha, Jakarta: Kencana Predana Media Group, hlm. 56. 


\author{
Ketua : Asep \\ Sekretaris : Saepudin \\ Bendahara : Yuyu Rohanah \\ Pengelola Koperasi Kelompok \\ Tani Bibilintik II sebagai berikut: \\ Ketua : Herni Yulianti \\ Sekretaris : Noneng/Lilih \\ Bendahara : Yuyum
}

Hal-hal yang berkaitan dengan manajerial koperasi kelompok tani Bibilintik II telah diatur dalam AD/ ART Koperasi Kelompok Tani Bibilintik II yang akan dilampirkan dalam laporan ini. Penjabaran tersebut merupakan bukti yang diharapkan dapat mendorong semangat anggota koperasi Kelompok Tani Bibilintik II dalam menjalankan roda ekonominya. Dalam kaitannya terhadap pembangunan desa maka koperasi ini akan dapat menjadi salah satu tonggak kokohnya perekonomian masyarakat Desa Lengansari.

4) Penyerahan dokumen terkait oleh pembimbing KKN kepada Aparatur Desa.

\section{b) Implikasi Terhadap Pendidikan.}

Koperasi sangat berpengaruh terhadap pendidikan baik dari segi sosial yang berdasarkan asas kekeluargaan dan sistem kerja yang gotong royong maupun dari segi ekonomi yang merupakan gerakan ekonomi pro rakyat yang sangat menjunjung kebhinekaan. Implikasi koperasi terhadap pendidikan salah satunya adalah koperasi mencerminkan nasionalisme. Pelajaran nasionalisme sering kali tidak diajarkan secara langsung di sekolah namun dapat dipelajari dengan penegakan ekonomi yang mencirikan ke-khasan Indonesia.

\section{PENUTUP}

1. Kesimpulan

Desa Lengansari merupakan Desa yang potensi utamanya berbasis pertanian. Petani di Desa Lengansari mayoritas merupakan petani bunga. Sebagian kecil petani tersebut merupakan petani padi, palawija, papaya, dan lain-lain. Desa Lengansari merupakan sebuah desa yang telah dianugerahi tanah subur yang potensial dan petani yang mumpuni sehingga untuk mengoptimalisasi potensi tersebut hanya perlu satu koneksi lagi pada sumberdaya modal.

Untuk mengakumulasi modal yang dimiliki masyarakat maka diperlukan sebuah mesin yang dapat menghimpun dana-dana masyarakat dimana system kerjanya harus sesuai dengan karakter masyarakat yang kekeluargaan dan sederhana. Solusi untuk permasalahan tersebut adalah pembentukan koperasi. Maka, dibentuklah sebuah koperasi di Desa Lengansari yang dioperasionalkan di Kp. Cibalung Rt. 04/04 Desa Lengansari kecamatan Sukaraja kab. Sukabumi yang bernama Koperasi Kelompok Tani Bibilintik II.

\section{Saran}

Koperasi Kelompok Tani Bibilintik II binaan kelompok III KKN STKIP-PGRI Sukabumi 2016 mestilah masih dalam taraf sederhana yang jika diibaratkan seperti balita yang masih merangkak, berdiri, dan belajar berjalan. Sehingga, saya pribadi dan rekan satu kelompok hanya berharap dan menitip pesan agar anggota Koperasi Kelompok Tani Bibilintik II tetap kompak dalam situasi apapun. Seperti peribahasa yang sering kita dengar "Bersatu kita 
teguh, bercerai kita runtuh". Jaya Koperasi Kelompok Tani Bibilintik II

\section{UCAPAN TERIMA KASIH}

Alhamdulillah, puji syukur penulis panjatkan kehadirat Allah SWT karena atas limpahan rahmat dan karunia-Nya sehingga artikel jurnal pengabdian ini dapat terselesaikan. Tak lupa pula penulis mengirimkan salam dan shalawat kepada Nabi Besar Muhammad SAW yang telah membawa umat Islam ke jalan yang diridhoi Allah SWT.

Terwujudnya skripsi ini tidak lepas dari partisipasi dan bantuan dari berbagai pihak. Oleh karena itu, penulis ingin menyampaikan terima kasih yang setulus-tulusnya kepada:

1. Drs. H. Isa Ismail, M.Pd. selaku Ketua STKIP PGRI Sukabumi;

2. Drs. Wawan Hermawan M.Pd. selaku Waka I Bidang Akademik dan;

3. Drs. Joko, M.Pd. selaku Waka II Bidang Administrasi dan Kevangan;

4. Dr. Sri Aryani, M.Pd. selaku Ketua LPPM STKIP PGRI Sukabumi;

5. R. Edy Rachmadio, S.Pd., M.Si. selaku Kaprodi Pendidikan Ekonomi sekaligus ketua panitia KKN tahun 2016;

6. Kepala Desa LengansariKecamatan Sukaraja-Kabupaten Sukabumi;

7. Masyarakat Desa Lengansari dan juga seluruh aparatur Desa Lengansari;

8. Mahasiswa Kelompok III wilayah penempatan di Desa Lengansari;

9. Serta seluruh pihak yang ikut membantu, baik secara langsung maupun tidak langsung. Penulis hanya bisa berdoa, semoga Allah membalas kebaikan-kebaikan mereka dengan setimpal. Amin. Besar harapan penulis, semoga skripsi ini dapat bermanfaat dan dapat bernilai positif bagi semua pihak yang membutuhkan.

\section{DAFTAR PUSTAKA}

\section{A. Buku}

Firdaus, Agus Edhi Susanto, (2002), Perkoperasian Sejarah, Teori dan Praktek, Jakarta: Ghalia Indonesia.

Hendar, Kusnadi, (2005), Ekonomi Koperasi Edisi Kedua, Jakarta: Fakultas Ekonomi Ul.

Herdiansyah, Haris, (2010), Metode penelitian kualitatif. Jakarta: Selemba Humanika.

Mardikanto, T, (1993), Penyuluhan Pembangunan Pertanian, Surakarta: Sebelas Maret University Press.

Moleong, Lexy J, (1991), Metode Penelitian Kualitatif, Bandung: Remaja Rosda Karya.

Pachta W, Andjar, Dkk, (2007), Hukum Koperasi Indonesia pemahaman, regulasi, pendidikan, dan modal usaha, Jakarta: Kencana Predana Media Group.

Presiden Republik Indonesia, (1992), Undang-Undang Republik Indonesia Nomor 25 Tahun 1992 Tentang Perkoperasian.

Rakhmat, Jalaludin, (2000), Metode Penelitian Komunikasi, Bandung: Remaja Rosdakarya.

Sitio, Arifin Dkk, (2006), Koperasi: Teori dan Praktek, Jakarta: Erlangga. 
Thoby, Mutis, (2004), Pengembangan Koperasi, Jakarta: Grasindo.

B. Jurnal

Ilo, (2015), Cooperatives and the Sustainable Development Goals: A Contribution to the Post-2015 Development Debate A Policy Brief. International Labour Organization: International Cooperative Alliance.

Trimo, S, (2006), Evaluasi Penyuluhan Pertanian Permasalahan dan Upaya Pemecahannya di Kecamatan Banyudono Kabupaten Boyolali. Jurnal Penyuluhan, Vol. 2. 
Ari Riswanto

Journal of Empowerment

Vol. 1, No. 1, Juni 2017 